\title{
Some changes in the flora and vegetation of algae in freshwater environments*
}

\author{
Ursula Geissler \\ Institut für Systematische Botanik und Pflanzengeographie der Freien Universität Berlin; \\ Altensteinstr. 6, D-1000 Berlin 33
}

\begin{abstract}
Changes in the flora and vegetation of algae are discussed with regard to the following aspects: (1) Changes in the distribution of an individual taxon (new colonizations and extinctions); (2) Changes within one group of algae over some decades (examples: desmids of two nature reserves between 1925 and 1980, and charophytes in the region of Berlin since 1800) or over longer periods of time (for example: analysis of diatom frustules in lake sediments since the glacial periods); (3) Changes in the algal flora within a region (for example: the phytoplankton of a small lake in Berlin in 1909 in connection with the restoration of this lake by R. Kolkwitz as compared with the phytoplankton in 1983, or the attempt to show the development in the algal flora in Berlin (West) by a survey of all data available and by planned investigations). - The interpretation of these data often proves difficult due to the problems regarding nomenclature, taxonomy and determination as well as the discontinuity in research, and the different methods applied. Finally, the importance of old reports and the need for modern research are emphasized. "Red Lists" of algae point to the urgent necessity of maintaining as many natural ecosystems as possible.
\end{abstract}

\section{INTRODUCTION}

Changes in the flora and vegetation of algae can occur continuously and very fast, especially in microphytes with their short sequences of generation. In the present paper, neither diurnal changes will be discussed (such as plankton migrations or migrations of intertidal diatoms) nor seasonal changes (such as spring or midsummer aspects of a site) nor the differences in the occurrence of algae in a particular habitat over two subsequent years. Instead, the long-term changes will be described here, both those caused naturally (such as by the phases of succession of a lake) and those caused mostly by man. This study will focus on changes in the flora that is in the spectrum of species in a specific region, under three different aspects.

\section{CHANGES IN THE DISTRIBUTION OF A SINGLE TAXON}

Changes in the distribution of a taxon, both extensions and reductions of areas, have been recorded in many marine species (i.a. see Boalch, 1987; Jones, 1974; Lüning, 1985). Up to now, there is little information concerning freshwater species.

\footnotetext{
- Dedicated to Dr. Dr. h. c. P. Kornmann on the occasion of his eightieth birthday.
} 
Taxa are able to colonize new regions by migrating step by step or they conquer new biotopes by overcoming large distances. Finds are always particularly striking when they are discovered far away from an original habitat; e.g. the red alga Compsopogon hookeri Montagne in the river "Erft" warmed up by cooling waters (a tributary of the "Rhine" in the western part of Germany; Friedrich, 1966), and the brown alga Ectocarpus confervoides (Roth) Kjellman in the salt-stressed river "Werra" (a headstream of the "Weser" in the western part of Germany; Geissler, 1983). For the biologist, two aspects are interesting:

- How did the species manage to arrive at the new site?

- What conditions at the site enabled its colonization?

Did the species occupy an ecological niche, that was vacant until then, or did it replace another species?

The above mentioned extensions of areas, however, ar in contrast with reductions of areas, even going as far as extinction of the species. For instance, the brown alga Pleurocladia lacustris A. Braun, a rare species found in earlier times in extensive waters of the North German plain, was also found in the surroundings of Berlin; the last proof, however, dates back to 1882 . The same applies to the red alga Thorea ramosissima Bory, living in slowly flowing, oligo- to mesotrophic waters, which was last found in Berlin in 1949 (Geissler \& Gerloff, 1982). Knowledge on the distribution of many microphytes is particularly small that one has to agree with Whitton $(1974$, p. 134): "Algae . . might well become extinct nationally without any algologist realizing the situation."

\section{CHANGES WITHIN GROUPS OF ALGAE}

Thorough investigations, when available, covering longer periods of time, reveal changes within a group of algae at a site relating to changes in its environmental conditions. So, for instance, in the area of the "Pechsee" and the "Barsee", two nature reserves in the "Grunewald" in Berlin (West), the number of desmid taxa has decreased by one fifth since 1925 . However, not only the diversity but also the spectrum of the species has changed during this period; lately, there have been 21 reoccurrences of finds and 41 losses, but also 23 new finds. As there has been a change in these two areas especially in the quantity and the quality of the water and consequently in the plant associations, the flora of the Desmidiaceae has changed in different ways in the various microhabitats: while the quantity of species living on the mud surface has increased slightly, the quantity of species living on sphagnum-cushions has decreased more distinctly. Moreover, our comparisons have shown that especially the rare species have decreased, while newly found taxa can often be characterized as frequent and as having wide ecological tolerances (Weddigen \& Geissler, 1980).

Investigations carried out in Switzerland (Werner, 1977) and the Netherlands (Coesel et al., 1978) revealed similar tendencies,

Charophyta are especially suitable for such comparative studies as they are often well documented in literature and in herbaria. At first, a survey of all records in Berlin (West) seemed to show a decrease from 23 to 1 species (Gutowski, 1984). Here, a graphic method was developed representing the finds of the various taxa (y-axis) over the years $(\mathrm{x}$-axis) by a point, whereby the disappeared species are lined up beneath the zero line and the species still existing above the zero line (see Fig. 1). This diagram makes it clear 
that in this group of algae the greatest changes had already taken place before 1910 , when the city of Berlin had developed into a metropolis and into a centre of industry. In 1985, a comprehensive exploration at more than 100 potential sites in Berlin (Flöter, 1985) revealed that in that year 5 different Chara- and Nitella-species were present at 13 sites, so that the diagram could again be slightly altered (Fig. 1). Obviously, at least some taxa of the Charophyceae are more tolerant ecologically than had been realized so far. Moreover, several species are able to colonize even strongly anthropogenic sites (such as gravel pits, drainage ditches, artificial ponds).


Fig. 1. Records on Charophyta in Berlin (West) over the past 188 years. Each point represents a record of a particular taxon ( $\mathrm{y}$-axis) in a particular year ( $\mathrm{x}$-axis). The species recorded have been numbered (see list and $y$-axis). The disappeared taxa are lined beneath the zero line (with a minus sign) and the taxa still existing above the zero line (with the plus sign)

Investigations over very long periods are of special interest, as they help to characterize the development of waters and landscapes. Diatoms (in addition to the remains of other organisms) are especially suited as their valvae remain well maintained in the sediment. Thus, within an interdisciplinary project the analysis of the flora of diatoms of late pleistocene and holocene sediments from the river "Havel" in Berlin was a contribution to the research of the post-glacial development of this river system (Bertzen, 1979, 1985).

\section{CHANGES IN THE FLORA OF ALGAE WITHIN A REGION}

The "Lietzensee", a small lake in the Berlin district of Charlottenburg, is an especially suitable example for assessing the changes in the algal colonization. It became known because, here in 1912, Kolkwitz successfully carried out the first lake restoration, 
by "rinsing" the lake with groundwater poor in nutrients. His publications (Kolkwitz, $1909,1914)$ seemed suitable for a comparison with the results of a reinvestigation (Heckelmann, 1983). Based on the data presented up to now i.a. the following results were obtained:

(1) essential changes in the chemical parameters of the lake cannot be recognized;

(2) possibly, phytoplankton diversity has increased: in 1983 more taxa were identified than had been recorded by Kolkwitz; however, the different methods used should be considered

(3) the spectrum of the species has changed; in the two investigations there were only four species in common;

(4) the proportion of the various groups of algae to the whole spectrum of species has also changed considerably: while the taxa of the Chlorophyceae have always presented the largest part, the proportion of species in the Cyanophyceae and in the various groups of flagellates has changed significantly;

(5) in late summer the members of the genus Oscillatoria still dominate while in the winter plankton the species previously dominant have now been replaced by different ones;

(6) nutrient loading is high i the degree of saprobity is still within mesosaprobic range.

For some time now, we have been trying to compile a survey, as comprehensive as possible (Gutowski, 1984; Gutowski \& Geissler, 1987) concerning the data on algal finds in Berlin (West). Principally, this region seems to be well investigated; however, over the decades, there have been considerable differences as to the research (intensity, issues, waters, and methods; see "Discussion").

The preliminary results are as follows:

(1) In Berlin (West) a total of 875 algal taxa has been recorded so far. This exceeds comparable checklists (cf. Whitton [1974] for the Isle of Mull) with regard to the absolute quantity of taxa as well as to the number of taxa per $\mathrm{km}^{2}$. This may be the result of a long research tradition on algae and limnology and a broad diversity of biotopes in Berlin.

(2) As in the checklist on the Isle of Mull the greatest number of species in Berlin can be found in the Bacillariophyceae; approximately 370 species of diatoms represent about $42 \%$ of all species; this is followed by the number and proportions of species in the Chlorophyceae, Conjugatophyceae and Cyanophyceae.

(3) Comparing records up to 1930 with those since 1951 we find, to our surprise, increasing numbers of taxa in several classes. This should be reexamined: it might be the result of an increase in research rather than in the diversity of algae.

(4) Detailed comparisons show that in some groups of algae the species numbers may be approximately constant, but the composition of the species spectrum has changed.

The graphic method used here offers good possibilities for the interpretation of these finds over a longer period of time (cf. the above discussion on charophytes, and Fig. 1). The diversity within a group of algae, the constant occurrence of species, the disappearance of species, the reappearance of species and a change in the spectrum of species are depicted.

The present survey on the finds in our region forms the basis for further research aiming at demonstrating changes in the flora of the algae. 


\section{DISCUSSION}

Primarily, the ba s is of such comparative studies on the flora of algae is formed by all facts published. Moreover, herbarium material, slides, conserved material as well as cores from water sediments may be analysed. However, it often turned out that data and material were not available in sufficient quantities or could only be used with restrictions. Difficulties in comparing: The comparison of records on algal taxa from different periods often meets with great difficulties. The nomenclature is an important aspect here: a lot of synonyms have to be eliminated first, and it cannot always be ascertained beyond doubt which taxon the respective scientist did observe. The reason for this may also lie in the $\operatorname{tax}$ on o $\mathrm{my}$, for often the understanding of a species has changed over the last decades, sometimes even several times. In some groups of algae, problems of identification play a part: the fact that there are no or few records may just mean that the taxa cannot be identified easily. This might be the reason for the current sparse number of records of blue algae in the rivers and lakes of Berlin. Thus, our diagrams sometimes show a distinct accumulation of points in the period after a new flora had been published (i.e. in the Xanthophyceae after Ettl, 1978). In addition, the discontinuity of research must be included in the interpretation of the data: over the years not only the problems (i.e. occurrence of desmids, of indicators of the saprobic system, investigation of different biocoenoses such as plankton or periphyton) have changed, but also the waters investigated, even in such as relatively small region as the western part of Berlin. Furthermore, in our city the problems involved have been dealt with sometimes by a lot of scientists and sometimes only by a few, all of these pursuing varying interests and possessing diverging areas of knowledge. Thus, it is quite obvious that a distinct peak in our diatom diagram cannot be attributed to the fact that these algae have suddenly immigrated to a larger extent into our rivers and lakes but to the fact that since the mid-fifties more botanists (including the members of my scientific team) have been doing research into this field. However, the methods of these scientists differ greatly, e.g. with regard to the types of sampling, time and frequency of sampling, evaluation of the samples, conservation state of the samples. This affects especially the evaluation of the changes in the algal vegetation.

The above list shows that the possibilities of comparisons are rather restricted.

The causes of the identified changes in the algal flora can be summarized as follows:

(1) loss of biotopes, esp. of very small waters;

(2) establishment of new, man-made biotopes

(3) changes in the biotopes, e.g. by embankments;

(4) changes in the water regime, e.g. lowering of the groundwater level, changes in the flow velocity;

(5) changes in water quality, e.g. eutrophication, acidification.

Pros pects: Finally, considering these changes and their causes, the question of how research should be continued becomes essential. As only fragments of changes in the algal flora can be recognized, as many data as possible must be collected. As a basis of reference more consideration should be given to older documents (such as publications, herbaria, collections of slides and samples). New investigations should focus on special problems; either a re-examination of a certain biotope, comparing 
it with its previous conditions or special research into a particular group of algae (see Charophyceae) should be carried out. Thus, our survey of the data on Chrysophyceae collected so far can be interpreted as showing that there has lately been an enormous reduction of this flora in Berlin. This statement does not seem to be substantiated, for ecological reasons. In the meantime, a planned search especially for representatives of the Chrysomonadales has brought forth a considerable number of new taxa (for Berlin) and their sites (Gutowski, 1984 and 1987). If, due to the lack of records from previous times, it is not possible to make comparisons, we should today lay the foundation for future research.

These investigations indicate the endangerment or even the extinction of species. In contrast to other groups of organisms, there are hardly any "Red List s" of algae. Krause (1984) prepared a survey of the Charophyta, according to which 28 of the 34 taxa found in Germany (that is $82 \%$ ) are listed as being endangered in different degrees. A further "Red List" is aimed at the red and brown algae in freshwater environments in Germany (Friedrich et al., 1984), the former and present distribution of which is little known to us. It is especially striking that there are hardly any reports on the expansion of a known vegetation or of new colonizations (Friedrich et al., 1985). Probably, all four species of the Phaeophyta in freshwater environments are threatened by elimination, nearly all 28 species of the Rhodophyta are presumably highly threatened.

A disappearance of organisms from the earth - which would mean a loss of irrecoverable genetic material and an impoverishment of complex ecosystems - should be considered as serious and as alarming in view of the high and rapidly increasing quantities of extinct taxa. "Red Lists" can only draw our attention to the various dangers. As, in contrast to some other groups of organisms, a protection of algal species is impossible, only a comprehensive and world-wide protection of ecosystems can slow down this alarming development. Moreover, we have to insist that our habitat be maintained as a whole and as natural as possible.

\section{LITERATURE CITED}

Bertzen, G., 1979. Darstellung der postglazialen Diatomeenflora des Tegeler Sees anhand von ausgewählten Sedimentproben und Versuch einer Rekonstruktion des Seencharakters. Staatsexamensarb. Berlin, 143 pp.

Bertzen, G., 1985. Diatomeenanalytische Untersuchungen an spätpleistozänen und holozänen Sedimenten des Tegeler Sees. Diss., Freie Univ., Berlin, 117 pp.

Boalch, G., 1987. Changes in the phytoplankton of the western English Channel in recent years. - Br. phycol. J. 22, 225-235.

Coesel, P. F. M., Kwakkestein, R. \& Verschoor, A., 1978. Oligotrophication and eutrophication tendencies in some Dutch moorland pools, as reflected in their desmid flora. - Hydrobiologia 61 , 21-31.

Ettl, H., 1978. Xanthophyceae I. In: Süßwasserflora von Mitteleuropa. Hrsg. von H. Ettl, J. Gerloff \& H. Heynig. Fischer, Stuttgart 3, 1-530.

Flöter, C., 1985. Untersuchungen zum Vorkommen von Characeen (Armleuchteralgen) in Berlin. Staatsexamensarb., Berlin, 174 pp.

Friedrich, G., 1966. Compsopogon hookeri Montagne, neu für Deutschland. - Nova Hedwigia 12, $399-403$.

Friedrich, G., Geissler, U. \& Gerloff, J., 1984. Vorläufige Liste der Braun- und Rotalgen des Süßwassers (Phaeophyceae und Rhodophyceae). In: Rote Liste der gefährdeten Tiere und 
Pflanzen in der Bundesrepublik Deutschland. Hrsg. von J. Blab, E. Nowak, W. Trautmann \& H. Sukopp. Kilda, Greven, 187-189.

Friedrich, G., Geissler, U. \& Gerloff, J., 1985. Freshwater rhodophytes of the Federal Republic of Germany: are their changes in distribution and frequency caused by man? - Poster and abstract. 2nd International Phycological Congress, Copenhagen.

Geissler, U., 1983. Die salzbelastete Flußstrecke der Werra - ein Binnenlandstandort für Ectocarpus confervoides (Roth) Kjellman. - Nova Hedwigia 37, 193-217.

Geissler, U. \& Gerloff, J., 1982. Veränderungen in der Algenflora Berlins. - Landschaftsentwicklung und Umweltforschung 11,141-149.

Gutowski, A., 1984. Zusammenstellung und Diskussion einer Florenliste von Algen für das Stadtgebiet von Berlin (West) anhand von Literaturdaten. Staatsexamensarb., Berlin, 208 pp.

Gutowski, A., 1987. Seasonal succession of scaled chrysophytes in a small lake in Berlin. Proceedings of the 2nd International Chrysophyte Symposium, Berlin 1987 (in press).

Gutowski, A. \& Geissler, U., 1987. Contributions to the knowledge of the algal flora of Berlin (West) and their changes. - Poster and abstract. 14th International Botanical Congress, Berlin.

Heckelmann, H., 1983. Ausgewählte Untersuchungen zur Kenntnis des Phytoplanktons im Berliner Lietzensee. Staatsexamensarbt, Berlin, $137 \mathrm{pp}$.

Jones, W. E., 1974. Changes in the seaweed flora of the British Isles. In: The changing flora and fauna of Britain. Ed. by D. L. Hawksworth. 97-113.

Kolkwitz, R., 1909. Über die Planktonentwicklung der Gewässer, erläutert an Oscillatoria agardhii Gom. - Landw. Jb. 38, (ErgBd. 5), 449-472.

Kolkwitz, R., 1914. Über die Ursachen der Planktonentwicklung im Lietzensee. - Ber. dt. bot. Ges. $32,639-666$.

Krause, W., 1984. Rote Liste der Armleuchteralgen (Charophyta). In: Rote Liste der gefährdeten Tiere und Pflanzen in der Bundesrepublik Deutschland. Hrsg. J. Blab, E. Nowak, W. Trautmann \& H. Sukopp. Kilda, Greven, 184-187.

Lüning, K., 1985. Meeresbotanik. Thieme, Stuttgart,"375 pp.

Weddigen, U. \& Geissler, U., 1980. Vergleichende Untersuchungen zur Algenflora zweier Berliner Naturschutzgebiete (Pech- und Barsee) mit besonderer Berücksichtigung der Desmidiaceen. Nova Hedwigia 33, 95-144.

Werner, E., 1977. Desmidiaceen im Hudelmoos. - Mitt. thurgau. naturf. Ges. 42, 7-98.

Whitton, B. A., 1974. Changes in the British freshwater algae. In: The changing flora and fauna of Britain. Ed. by D. L. Hawksworth. Acad. Press, London, 115-141. 